\title{
Spatial inequalities from an East Central European perspective: Case studies from Hungary
}

\section{Ferenc Gyuris}

\section{(2) OpenEdition \\ 1 Journals}

\section{Electronic version}

URL: http://journals.openedition.org/espacoeconomia/5186

DOI: 10.4000/espacoeconomia.5186

ISSN: 2317-7837

\section{Publisher}

Núcleo de Pesquisa Espaço \& Economia

\section{Electronic reference}

Ferenc Gyuris, «Spatial inequalities from an East Central European perspective: Case studies from Hungary ", Espaço e Economia [Online], 13 | 2018, Online since 22 December 2018, connection on 24 September 2020. URL : http://journals.openedition.org/espacoeconomia/5186 ; DOI : https://doi.org/ 10.4000/espacoeconomia.5186

This text was automatically generated on 24 September 2020.

(C) NUPEE 


\title{
Spatial inequalities from an East Central European perspective: Case studies from Hungary
}

\author{
Ferenc Gyuris
}

\section{Spatial inequality: an evergreen topic, especially in these days}

1 Spatial inequality belongs to the globally most popular issues in current geography as well as a wide range of social sciences that have interests in spatial phenomena, such as regional economics or urban sociology (Gyuris, 2014, 2017). This interest comes first from remarkable social challenges over the last decades, which are present at the most diverse geographical scales - from a still striking gap between countries of the Global North and Global South (e.g. Gyuris, 2018a, Solarz, 2014) to growing regional disparities in many countries to increasing inequalities within urban spaces. Second, the global crisis of 2008-2009 opened the way for intensified criticism on globally dominant social and economic policies as well as their underlying moral foundations. Third, for inequality is present in all human societies, it constitutes a fundamental moral issue about which every human being has some experience and from which many people suffer from. These phenomena are shaping social realities all around the world, but are especially tangible in societies with a traditionally high level of disparity as well as in countries and regions owing a semi-peripheral or even peripheral position in global power relations. In fact, people in South American countries, be they scholars or inhabitants of poor urban districts, have had a long experience with both.

2 A considerable part of related studies in international scientific research addresses one of the following three topics:

3 The remarkable social and economic challenges in urban areas, which the 2008 global crisis further intensified. Here the major themes are increasing neighborhood segregation, polarized and precarious labor markets, and a relative lack of housing 
projects for less affluent social groups (Fincher \& Iveson, 2012, MacLeod \& McFarlane, 2014), intensifying debates around the right to public spaces in the cities (MacLeod, 2011, Harvey, 2012) as well as the extreme global mobility of "fast" urban policies (such as those aimed at creating "creative cities", "smart cities" etc.), which are copied worldwide for certain attractive features (Peck \& Theodore, 2010, Temenos \& McCann, 2013, Temenos \& Ward, 2018), but in fact rather intensify already existing problems instead of curing them (Gerhard, Hoelscher \& Wilson, 2017).

Unevenly changing regional inequalities with shifting philosophies of regional development after the global crisis. A number of studies focuses on national and international (such as EU) policies that increasingly neglect socially and economically impoverished regions in the name of concentrating public resources in, and diverting private resources to, "more competitive" regions in order to speed up overall economic growth (Petrakos et al., 2011), a process favoring large urban agglomerations and global city-regions (Paddison \& Hutton, 2015, Harrison \& Hoyler, 2015).

Criticism on economic and social policies hallmarking the turn of the millennia at the global scale, as well as their underlying moral concept, which have played a big role in the global crisis and the new disparities it brought into being. Especially influential have been the seminal works of Richard Wilkinson and Kate Pickett (2009) in life sciences, Joseph Stiglitz (2012), Thomas Piketty (2014), Francois Bourguignon (2015) and Branko Milanović (2016) in economics and Walter Scheidel (2017) in history, all having exerted strong impact on the international political and public discourses as well, on the challenges posed by increasing social disparity. Papers addressing the same topics and even reacting to some of the above works from a geographical perspective have also been published in an increasing quantity (Sheppard 2015, Lindner 2016). Thus, it has become a major attempt to open up the "black box" of dominant academic concepts on why inequalities emerge and how they can be managed and cured, and to enable a firm reconceptualization of disparity research, including the investigation of spatial inequalities, in light of the new trends.

\section{Brazil and Hungary: some chances to better understand each other's context}

6 Whereas the relevance of inequality related issues is certainly evident for a Brazilian readership, one also has to underscore their prime importance in East Central European countries. This might sound unusual considering that much cited and acknowledged international rankings usually refer to Brazil as one of the most unequal societies of the world, whereas Hungary and other East Central European countries (e.g. Poland, Czechia and Slovakia) have rather low numbers in such a comparison, at least in terms of income. The most up-to-date edition of the CIA World Factbook, for example, reports a Gini index of 49.0 for Brazil in 2014 (in terms of distribution of family income), placing the country in the top 20, but only 28.2 for Hungary in 2015 (between 30.8 in Poland and 25.0 in Czechia), positioning it among the 20 most equal countries of the world (CIA, n.d.). Yet, the collapse of the Communist regime in Hungary in 1989-1990, the shock of transition to a democratic society and market economy, and, more recently, the impact of the global crisis of 2008-2009 and the policy measures following it have created new forms of disparity, while also making some sorts of already existing inequality more and more accentuated. 
7 Furthermore, although Brazil and Hungary are not comparable in absolute numbers, since the former is more than 21 times bigger in population size and more than 12 times in nominal GDP (IMF, 2018), they have some important similar features from the perspective of spatial disparities. Depending on the terminologies used by various scholars, both countries belong to the global semi-periphery in a Wallersteinian conceptual framework (e.g. Wallerstein, 2004), with similar positions in global production networks (for the concept see Yeung, 2005, Yeung \& Coe, 2015), and they also represent, at least in the approach of radical scholars, partly similar forms of peripheral capitalism.

8 In addition, both countries experienced transition from a dictatorship to a plural democracy during the 1980 s and 1990s, with new trends of increasing political centralization in the recent years. The pattern of spatial inequalities has significant parallels, too. In Brazil, the dominance of the highly urbanized Southeastern Region in economic and power relations is still out of question despite of the manifold development projects in other regions during the last sixty years in order to give impetus to less central regions. In Hungary, the capital city of Budapest concentrated $17.9 \%$ of the national population, $36.1 \%$ of the GDP, $54.9 \%$ of the students in higher education, 59.5\% of R\&D employees and $63.1 \%$ of the companies with FDI in 2016 (KSH, n.d.). Besides, similarly to the Southeast-Northeast development divide in Brazil, inequalities in Hungary tendentiously decline from the Northwest (close to the European economic core area in general, and Austria, one of the economically most developed countries of Europe, in particular) to the East. In fact, these disparities have permanently existed in the last more than one hundred years, which means remarkable historical endurance (Győri \& Mikle, 2017, Demeter \& Szulovszky, 2018). Last but not least, spatial inequality has been intensively shaped in Hungary by additional development funds provided by the European Union since the country's EU accession in 2004, and related experience can be relevant for several South American countries within the UNASUR framework.

\section{The Hungarian case}

9 The papers in the current special cluster are products of a scholarly collective related to Eötvös Loránd University (ELTE), Institute of Geography and Earth Sciences in Budapest, Hungary, especially its Department of Regional Science. ELTE is the largest and oldest university in Hungary (founded in 1635), and one of the most renowned ones in East Central Europe. It hosted the first geography department in Hungary, which was established in 1870 and has developed since then into a conglomerate of four departments. The predecessor of the Department of Regional Science was founded in 1952 as Department of Descriptive Geography, renamed Department of Regional Geography in 1954 and gaining its current name in 2007. It was from the very beginning dedicated to taking a broader geographical perspective, not only concentrating on Hungary, but placing it in the international, and even global, context. This academic collective is also devoted to combine theoretical and methodological research with practical decision-aiding in various domains of public administration and the economy, including various research institutes of the Hungarian Academy of Sciences (MTA), several ministries and their background institutions such as the Hungarian Central Statistical Office (KSH), and an array of private companies where former students of the 
department are working in considerable numbers. Most of the authors are also members of the Hungarian Geographical Society and/or the Hungarian Regional Science Association, which means their research gives insight into scientific work in these academic circles.

The authors of the current special "dossier" report on some major trends of spatial inequality in Hungary, embedding this specific case into international scholarly discourses and the most important social and economic trends. Ákos Jakobi, Brigitta Zsom and Zsófia Vida (2018) investigate some new forms of spatial disparity in the information age, revealing how new technologies and related means of governance are based on, and mostly intensifying, already existing inequalities between the regions and along the urban hierarchy. In broader sense, their paper provides a lot of inputs for both scholars and decision-makers in various countries to gain a more sophisticated understanding of the actual (limited) capacity of new technologies to reduce "old" forms of inequality.

11 László Czaller and Hajnalka Lőcsei (2018) discuss the link between disparities of skill distribution and unemployment in Hungary. Their findings provide sound evidence for the positive impact of improving human capital on decreasing unemployment. As they point out, increasing shares of high-skilled individuals are not only positive for pushing up average employment rates, but also because they have a firm positive impact on the employment of individuals with less human capital, too. Hence, their paper has important implications for decision-makers as well about how the development of social capital can play a significant role in coping with employment related challenges, even in relatively less developed regions.

Máté Farkas and Pál Szabó (2018) focuses on spatial inequalities in the European Union. Contrasting the official goals of the EU to increase territorial cohesion with actual trends after the mid-2000s, they convincingly present two conflicting tendencies. Whereas the difference between member states was decreasing considerably both before and after the global crisis of 2008-2009 in terms of various economic indicators (including per capita GDP and labor productivity), this was in many cases rather due to rapid improvement in some central regions in economically less developed member states, with regional inequalities within the same countries tending to increase further. The main findings of this paper teach us important lessons about how the EU planning regime could and should be improved, and, in more general sense, about several issues of utmost political and economic importance in any international organization aimed at promoting various forms of cooperation between its member states.

13 Finally, Péter Baji, Márton Berki and Éva Izsák (2018) take a long-term historical perspective in order to reveal the main mechanisms behind the urban development of Budapest, the capital city of Hungary. They pay special attention to the changing role of the inner city, and the impact of the post-communist transition on the process. Their study contributes to a better and locally more embedded contextualization of social and economic processes in the urban space, and identifies several trends along which Budapest and other international cities with similar dimensions can be compared.

14 While informing the much honored readers of Espaço e Economia about some cuttingedge results of their Hungarian colleagues, we consciously strive for opening up new channels of mutual communication in the global academia of the current epoch, where actors in various countries have highly uneven access to international arenas of knowledge production, which creates massive global spatial disparities in academic life, 
both before and after the crisis of 2008-2009 (Gyuris, 2018b, Jöns \& Freytag, 2016, Paasi, 2015). We are aware of how the representatives of many national and local academic contexts are effectively excluded from the global flows of knowledge production on social issues, such as that of spatial inequality, which also hinders their communication with each other. Hence, the current special issue is aimed at creating transversal academic ties between semi-peripheral academic milieus in order to establish a more inclusive discourse, to learn from each other, and to find more diverse answers to the problems posed by the global crisis and its outcomes and answers that are more feasible for geographical contexts outside the leading cores of the world economy and politics.

\section{BIBLIOGRAPHY}

Baji, P., Berki, M. \& Izsák, É. (2018). Transformation processes of the city center of Budapest: From historical development to the new economy. Espaço e Economia, 7(13)

Bourguignon, F. (2015). The Globalization of Inequality, Princeton (NJ): Princeton University Press. CIA (n.d.). The World Factbook. https://www.cia.gov/library/publications/the-world-factbook/. Accessed: December 17, 2018

Czaller, L. \& Lőcsei, H. (2018). Skill distribution and regional unemployment disparities in Hungary. Espaço e Economia, 7(13)

Demeter, G. \& Szulovszky, J. (Eds.) (2018). Területi egyenlötlenségek nyomában a történeti Magyarországon. Módszerek és megközelitések [In search of spatial inequalities in historical Hungary. Methods and approaches]. Budapest: Hungarian Academy of Sciences, Research Center for the Humanities \& Debrecen: University of Debrecen, Department of Human Geography and Regional Development.

Farkas, M. \& Szabó, P. (2018). Changing regional disparities in the European Union in the 2000s convergence from different aspects. Espaço e Economia, 7(13)

Fincher, R. \& Iveson, K. (2012). Justice and injustice in the city. Geographical Research, 50(3), 231241.

Gerhard, U., Hoelscher, M. \& Wilson, D. (Eds.) (2017). Inequalities in Creative Cities: Issues, Approaches, Comparisons, New York: Palgrave Macmillan.

Győri, R. \& Mikle, G. (2017). A fejlettség területi különbségeinek változása Magyarországon, 19102011 [Transformation of regional development disparities in Hungary, 1910-2011]. Tér és Társadalom, 31(3), 143-165.

Gyuris, F. (2014). The Political Discourse of Spatial Disparities: Geographical Inequalities Between Science and Propaganda, Cham: Springer.

Gyuris, F. (2017). Urban inequality: Approaches and narratives. In U. Gerhard, M. Hoelscher \& D. Wilson (Eds.), Inequalities in Creative Cities: Issues, Approaches, Comparisons (pp. 41-76). New York: Palgrave Macmillan. 
Gyuris, F. (2018a). Geographies of development in the twenty-first century. In M. W. Solarz (Ed.), New Geographies of the Globalized World (pp. 30-53). Abingdon, New York: Routledge.

Gyuris, F. (2018b). Problem or solution? Academic internationalisation in contemporary human geographies in East Central Europe. Geographische Zeitschrift, 106(1), 38-49.

Harrison, J. \& Hoyler, M. (Eds.) (2015). Megaregions: Globalization's New Urban Form? Cheltenham; Northampton (MA): Edward Elgar.

Harvey, D. (2012). Rebel Cities: From the Right to the City to the Urban Revolution. London; New York: Verso.

IMF (2018). World Economic Outlook Database, October 2018 Edition, https://www.imf.org/external/ pubs/ft/weo/2018/02/weodata/index.aspx. Accessed: December 17, 2018

Jakobi, Á., Zsom, B. \& Vida, Z. (2018). Dimensions of spatial inequalities in the Information Age: The case of Hungary. Espaço e Economia, 7(13)

Jöns, H. \& Freytag, T. (2016). Boundary spanning in social and cultural geography. Social \& Cultural Geography, 17(1), 1-22.

KSH (Hungarian Central Statistical Office) (n.d.). STADAT. http://www.ksh.hu/stadat. Accessed: December 16, 2018

Lindner, P. (2016). Problematising inequality. Geopolitics 21(3), 742-749.

MacLeod, G. (2011). Urban politics reconsidered: growth machine to post-democratic city? Urban Studies, 48(12), 2629-2660.

MacLeod, G. \& McFarlane, C. (2014). Introduction: Grammars of urban injustice. Antipode, 46(4), 857-873.

Milanović, B. (2016). Global Inequality: A New Approach for the Age of Globalization, Cambridge (MA): Harvard University Press.

Paasi, A. (2015). "Hot spots, dark-side dots, tin pots": The uneven internationalism of the global academic market. In P. Meusburger, D. Gregory \& L. Suarsana (Eds.), Geographies of Knowledge and Power (pp. 247-262). Dordrecht: Springer.

Paddison, R. \& Hutton, T. (Eds.) (2015). Cities and Economic Change: Restructuring and Dislocation in the Global Metropolis. London: SAGE.

Peck, J. \& Theodore, N. (2010). Mobilizing policy: Models, methods, and mutations. Geoforum, 41(2), 169-174.

Petrakos, G., Kallioras, D. \& Anagnostou, A. (2011). Regional convergence and growth in Europe: Understanding patterns and determinants. European Urban and Regional Studies, 18(4), 375-391.

Piketty, T. (2014). Capital in the Twenty-First Century, Cambridge (MA): Harvard University Press.

Scheidel, W. (2017). The Great Leveler: Violence and the History of Inequality from the Stone Age to the Twenty-First Century, Princeton (NJ) and Oxford: Princeton University Press.

Sheppard, E. (2015). Piketty and friends: Capitalism, inequality, development, territorialism. The AAG Review of Books, 3(1), 36-42.

Solarz, M. W. (2014). The Language of Global Development: A Misleading Geography, Abingdon, New York: Routledge.

Stiglitz, J. E. (2012). The Price of Inequality: How Today's Divided Society Endangers Our Future. New York; London: W. W. Norton \& Company. 
Temenos, C. \& McCann, E. (2013). Geographies of policy mobilities. Geography Compass, 7(5), 344357.

Temenos, C. \& Ward, K. (2018). Examining global urban policy mobilities. In J. Harrison \& M. Hoyler (Eds.), Doing Global Urban Research (pp. 66-80). London, Thousand Oaks, New Delhi, Singapore: SAGE.

Wallerstein, I. (2004). World-Systems Analysis: An Introduction. Durham (NC): Duke University Press. Wilkinson, R. \& Pickett, K. (2009). The Spirit Level: Why More Equal Societies Almost Always Do Better. London: Allen Lane.

Yeung, H. W. (2005). Rethinking relational economic geography. Transactions of the Institute of British Geographers, 30(1), 37-51.

Yeung, H. W. \& Coe, N. M. (2015). Toward a dynamic theory of global production networks. Economic Geography, 91(1), 29-58.

\section{AUTHOR}

\section{FERENC GYURIS}

Eötvös Loránd University (ELTE), Department of Regional Science

Email: gyurisf@caesar.elte.hu 